\title{
BREVE INTRODUCCIÓN AL ESTUDIO DE LA TRAGEDIA GRIEGA
}

José Barba*

\section{Primera parte}

\section{Inicio}

No han faltado a la dramaturgia contemporánea obras 'serias' y de gran valor literario. Cierto sentir social y filosófico de época en la vida de los países modernos ha auspiciado la creación de piezas antológicas que propician la introspección del individuo en sus problemas vitales o la reflexión, a veces oblicua, de la sociedad sobre algunas implicaciones del pasado que prefiguran y afectan su presente. Son, así, bien conocidas Casa de muñecas (1875), de Henrik Ibsen (1828-1906); Asesinato en la catedral (1936), de T.S. Eliot (1888-1965); A puerta cerrada (1943), de Jean Paul Sartre (19051980); Las brujas de Salem (1953), de Arthur Miller (1915-); Historia de una escalera (1949), de Antonio Buero Vallejo (1915), y El color de nuestra piel (1950), de Celestino Gorostiza (1905-1967), por citar algunos dramas. Otro mexicano ilustre, Alfonso Reyes (1889-1959), oculta en clave profundos sentimientos de dolor familiar en su Ifigenia cruel (1924). Y podemos recordar que, como en los tres siglos anteriores, muchos otros temas clásicos griegos fueron recreados, particularmente por dramaturgos franceses del siglo xx: Jean Giraudoux: $L a$

\footnotetext{
* Departamento Académico de Estudios Generales, ITAM.
} 
JOSÉ BARBA

guerra de Troya no sucederá (1935); Jean Anouilh: Antígona (1944), y Jean Cocteau, con su Orfeo (1926), en película también (1950). También nos viene a la memoria la excelente modernización fílmica de Fedra (1962), con Melina Mercouri, Raf Vallone y Anthony Perkins. Por otra parte, son muchas las obras de música clásica basadas en temas griegos, dramáticos o dramatizables: Christopher W. Gluck (1714-1787), por ejemplo, musicalizó Orfeo e Ifigenia en Áulide. Mas para la enorme mayoría de nuestros contemporáneos los cines y las salas de representación, si acuden a ellas, son simplemente una ocasión de entretenimiento.

No fue así para los antiguos griegos. Las obras más representativas de su asombroso teatro como sus más grandes creaciones arquitectónicas, surgieron de su sentido estético, pero también de su sentido religioso. Es significativo que haya sido precisamente en tiempos de Perícles (495-429 a.C.) cuando se lograran dos importantísimos hechos: la consumación del Partenón y la reinstitución de la representación de las tragedias en las Fiestas Leneas (de la fermentación del vino) en honor a Dionisos, oficializada primeramente por Pisístrato (600-527 a.C.). La tragedia y la técnica constructiva compartían el concepto de música. Como menciona Héctor Velarde en su Historia de la Arquitectura, “los griegos empleaban la palabra 'sinfonía' para este arte y, en las tardes doradas de Atenas, al contemplar el Partenón, decían: "Escucha, el Partenón está cantando.” Y Curt Sachs nos recuerda que "Platón recomienda a los guardianes de su Estado ideal que construyan los edificios inspirándose en el espíritu de la música.”

Como sabemos por las vidas de los filósofos griegos y como nos lo recuerda Fustel de Coulanges (1830-1889) en La ciudad antigua, para la 'polis' griega no existía separación entre religión y estado, y tanto la esplendidez de los monumentos religiosos, todos públicos, como las grandiosidad de las representaciones teatrales, las principales de ellas de inspiración mítica o teológica, eran para la ciudad 'una causa de interés nacional', como diríamos hoy. Domingo Mayor señala cómo Demóstenes (384-322 a.C.), en el primero de sus famosos discursos contra el imperialista Filipo II de Macedonia (360-336 a.C.), compa- 
raba la mayor atención de los atenienses a "la minuciosa organización y aun legislación tocante a las fiestas dionisíacas”, con merma de los preparativos militares mismos. Y se consideraba tan importante la participación del pueblo de Ática en tales acontecimientos anuales o semestrales, que se instituyó un fondo especial del erario público (el zeoorikón) para facilitar la asistencia por parte de los pobres de una población aproximada (hacia la segunda mitad del siglo V a.C.) de 115,000 personas, entre ciudadanos, extranjeros residentes, esclavos, mujeres y niños. La entrada individual al teatro (tres y cuatro piezas en un solo día), libre en sus comienzos, fue luego, en el siglo V a.C., de dos óbolos: exactamente el costo del mantenimiento diario de un 'hoplíta' o soldado de infantería. Es que para la antigüedad griega, aunque hubo también ateos virtuosos (Platón, en Las leyes, los considera precisamente como los ciudadanos más peligrosos), la buena vida cívica presuponía la religiosidad de los ciudadanos; y el teatro, por las razones que veremos, era un excelente vehículo de adoctrinamiento cívico-religioso.

\section{Los orígenes del teatro griego}

Nos han acostumbrado a oír hablar del 'milagro' de este pueblo superiormente dotado, como si se hubiese dado por encanto, por obra y gracia del esplendor casi plenamente espiritual de su cielo. Nikos Kazantzakis (1865-1957) nos dice en su Carta al Greco que "el grito turbio, mal decantado, del Oriente, al pasar por la luz de Grecia, se fija, se humaniza, se convierte en Palabra...”. Por su parte, los maestros de las artes plásticas nos hablan con toda naturalidad de 'la sonrisa ática’ de ciertas estatuas representativas. Pero Friedrich Nietzsche (1844-1900), en El origen de la tragedia (1871), nos recuerda que antes del triunfo de Apolo en la equilibrada formación normativa de la 'maestra del mundo', creadora de la perfección definitiva de las formas artísticas, urgían incontenibles fuerzas indómitas (dionisíacas) en las raíces mismas del viejo hombre heleno. Con fácil aplicación al Edipo 
JOSÉ BARBA

de Sófocles, Paul Diel, en su análisis psicoanalítico del simbolismo, muestra cómo las multiformes tendencias dionisíacas se centran en torno a la irascibilidad y la intemperancia indisciplinada.

La luz y la sombra se debaten en duelo terrible desde la Ilíada, ella misma una tragedia, manantial de temas trágicos. ("Esquilo -dice F. Nietzsche- llamaba a sus tragedias 'migajas caídas de la mesa de Homero’...”) Dionisos, divinidad tracia de remota procedencia oriental, en cuyo honor se celebran desde antes del siglo vi a. C. las primerísimas fiestas agrestes de la vendimia, del lagar y de la fermentación del zumo de la uva, es el dios de la ebriedad y del placer sensual, pero también es la deidad 'omestès' ('sanguinaria') de la orgía dolorida y macabra. Algunas figuraciones del arte antiguo nos recuerdan el modo truculento como terminaron quienes hubieron rechazado su culto.

Al margen de teorías no-dionisíacas, como la de William Ridgeway, para quien la tragedia se deriva del culto fúnebre a héroes individuales (Origin of Tragedy (1910), Gilbert Murray (1866-1957) supone que el ritual dionisíaco del drama homónimo debió reducirse a seis etapas: “1) Un ‘ágon’ o combate, en que el ‘dáimon’ lucha con su adversario... 2) Un 'pázos' o desastre, que comúnmente asume la forma de ‘spáragmos’ o descuartizamiento... 3) Un mensajero que trae la noticia de lo acontecido; 4) Una lamentación... 5) El descubrimiento o reconocimiento del dios oculto o desmembrado; 6) Su epifanía o manifestación en la gloria”. Este resumen, como lo señala el autor citado, se basa, a su vez, en opiniones 'ortodoxas' de críticos contemporáneos suyos. (Relaciónese esta partición con lo que se dirá muy sumariamente más abajo sobre la estructura de la obra dramática).

Así pues, la representación trágica griega tiene sus principios en una ambigua religiosidad de origen agropecuario (con clara referencia a la lujuria, los cantores del coro primitivo iban disfrazados de sátiros, pues tragedia significa literalmente ‘canto del macho cabrío'). Y procede de la transformación gradual de una forma de lírica coral ritual, algo hierática, llamada 'ditirambo', canto apasionado directamente relacionado con las celebraciones dionisíacas. Se considera que los himnos originarios fueron introduciendo partes narrativas y que cuando 
Thespis, primario autor dramático del siglo vi a. C., introdujo la innovación de que al ‘corifeo' le respondiese no todo el coro sino sólo uno de sus integrantes, apareció el embrión del diálogo dramático (Horacio: Espistola ad Pisones, v 275-7). Más tarde se adoptó como 'metro', o género de versos a sílabas contadas y con la colocación adecuada de sus respectivos acentos, el llamado ‘senario yámbico’ (verso con medida de seis pies bisílabos cortado en dos mitades desiguales), que-según Aristóteles- "es el que mejor imita el lenguaje de la conversación ordinaria” y, por ello, "muy apto -como observa oportunamente A. Espinosa Polit-para el duelo verbal, verso a verso, entre dos interlocutores”. M. Lenchantin con razón caracteriza el verso dactílico como 'triste', al verso jónico como 'voluptuoso', frente al verso yambo como 'mordaz'. Véase brevemente en este ejemplo:

Teiresias:

Pántes gar ú fronéite. Ego de ú mée póte

Tam'oos án éipoo mée ta s'ekféenoo kaká.

Oidípous:

Té fées; (?) ksineidóos ou fráseis, all'énnoeis

Jeemás prodóunai kai katafzéirai pólin; (?)

Teiresias:

Egó út'emautón úte s'alguinóo. Ti taut'

Álloos elénjeis; (?) Ú gar án pýzoió mú.

(Oidípous Týrannos, v 328-33)

"Tiresias:

Es que todos erráis. Mis males callo, ¡mis males! ¡ay! Por no decir... los tuyos!

Edipo:

¿Qué? ¿Tú sabes todo y en callar persistes?

¿Quieres ser tú la ruina de tu patria?

Tiresias:

Ni a mí ni a ti daré tormento en vano;

No insistas más; por mí no has de saberlo.”

(A. Espinosa Polit, Edipo Rey). 
JOSÉ BARBA

“En el idioma -nos dice Nietzsche en su Historia de la literatura griega (1874-1875) - el autor dramático gusta de la expresión difícil y enigmática (el verbo ‘ainéoo’ significa hablar ambiguamente) porque sabe que tiene un auditorio agudo en la materia...”

Y hay que tomar en cuenta que, para cuando Aristóteles (384-322 a.C.) analiza en su Poética las obras de los grandes trágicos griegos y establece las normas constitutivas de una buena obra dramática, han pasado cien años desde Esquilo (525-456 a.C.), Sófocles (495-405 a.C.) y Eurípides (480-406 a.C.), los tres grandes astros de la dramaturgia griega. Mas éstos escasamente tuvieron guía: fue su genio el que 'hizo camino al andar'.

En la transición de las obras originales del norte del Peloponeso hacia el mayor refinamiento del teatro del Ática, del ditirambo a la tragedia propiamente dicha, además de la mencionada introducción embrionaria del diálogo, se dieron otros cambios: se añadieron himnos en honor del héroe o divinidad local; se distinguió entre el parlamento individual y el canto propiamente dicho, reservado para las lamentaciones, la oración y la expresión de las emociones anímicas, y se eliminaron las escenas de tipo bufonesco o vulgar.

\section{La promoción del teatro por parte del estado}

Ya se habrá deducido que las obras dramáticas, por definición ('drama' significa ‘acción’ y 'zéatron’ alude a la misma raíz semántica de 'zeooréo’: ‘mirar’ y ‘zeooreetikós’: ‘contemplativo’), no son para ser leídas sino para ser representadas y vistas. Y al igual que Platón ordenaba, en Las Leyes, que la práctica religiosa no fuese privada sino colectiva, de igual modo el gobierno ateniense quería que la energía religiosa, social y psicológica emanada del teatro fuese vivida por grandes grupos de la ciudadanía congregada. Ya habíamos sugerido algo semejante desde el inicio de esta introducción. Diremos enseguida cómo y por qué esta inteligente visión político-religiosa intentaba utilizar el teatro como elemento unificador del mundo helénico. 
Antes de la promoción oficial de las obras trágicas, éstas tenían lugar sin gran solemnidad como representaciones rústicas hacia nuestro mes de diciembre y continuaron así por mucho tiempo. En el año 534 a.C. Pisístrato (600-527 a.C.), que mandó recopilar la Ilíada y la Odisea, ordenó oficialmente las representaciones trágicas durante las Fiestas Leneas, como ya se dijo. Y poco después del fin de las Guerras Médicas (490-479 a.C.) se instituyeron las Grandes Fiestas Dionisíacas, hacia marzo. A ellas eran invitados los aliados de Atenas, que en esa ocasión iban a llevar sus tributos. Se ve claramente cómo el teatro, por las fuentes de sus mitos comunes, por los temas de un pasado histórico y literario compartido y por los nexos religiosos de que todos aquellos pueblos comulgaban, era parte constitutiva muy importante del panhelenismo cultural.

El estado organizaba concursos de dramaturgia, seleccionando por suertes a los poetas trágicos concursantes, nunca más de tres. Al principio cada poeta trágico presentaba una trilogía 'ligada' por el mismo tema o personaje; después la trilogía 'libre’ pudo constar de obras no necesariamente relacionadas entre sí. Diez ciudadanos, dos por cada tribu, escogidos también por suertes, formaban el jurado calificador de las obras presentadas y otorgaban los premios a los ganadores. Por testimonios de la antigüedad, sabemos que de ciento ocho obras premiadas, Sófocles ganó con setenta y dos el primer premio y con treinta y seis, el segundo (¡entre estas últimas, Edipo Rey!). De ellas los azares de la historia nos dejaron solamente siete, aparte de un pequeño drama satírico titulado Los sabuesos y de algunos fragmentos de calidad insuficiente para determinar con certeza la dirección de otras preocupaciones morales y políticas del poeta. Sobre esto volveremos al final de la segunda parte de esta presentación.

Los concursantes seleccionados solicitaban al arconte (autoridad municipal de la ciudad) la aportación de un coro (de doce a quince miembros). Éste era subvencionado por las tribus de Ática. Y cada tribu encargaba a un ciudadano responsabilizarse del equipamiento y de los gastos de la empresa. Él escogía a un ‘joriféos’, maestro de coro; éste instruía a los ‘coréutas’ y seleccionaba a un acompañante 
JOSÉ BARBA

musical. El estado se encargaba de retribuir económicamente a los actores, a los músicos y a los autores, si bien la gloria de estos últimos, como la de los atletas vencedores en los Juegos Olímpicos, quedaba simbolizada más por la corona de laurel con la cual era ceñida su frente después del triunfo. La información acerca de los concursantes triunfadores se hacía instalando trípodes publicitarios que mostraban los nombres de los vencedores en las vías públicas.

IV. Los actores, la actuación, la acción, el canto, la música, el coro

El ‘corifeo’ dirigía las dos partes en que se dividía el coro. Los actores se reducían siempre al número indispensable. Con Sófocles el número de éstos llega a tres: protagonista, deuteroagonista y tritagonista. Como dijimos, ‘drama’ significa ‘acción’; y, como ésta engendra conflicto, la oposición crea también el ‘ant(i)-agonismo’ entre los personajes. En la actuación no participaban las mujeres. Pero hay que tomar en cuenta que los pocos actores podían desempeñar varios papeles, ya que las máscaras ('prósopa'), la vestimenta y los ‘coturnos’ (calzado de tacones muy altos) que usaban les daban las características distintivas, según la necesidad de la representación. Hay que pensar, además, que la reducción del número de los personajes acentuaba la concentración y la intensidad de la acción, de la pasión y, por ende, del diálogo. En ocasiones predeterminadas, para hacer resaltar al 'pázos' o sentimiento, al recitativo lírico o patético lo acompañaba el fondo musical de un solo de 'aulós', muy distinto del que se explicará a continuación. Más raramente se tocaba la cítara en el drama. Las voces cantaban acompañadas por el ‘aulós’. Era éste no una flauta, como se creyó durante largo tiempo, sino, según C. Sachs, un instrumento de sonido "no suave sino todo lo contrario, agudo e incitante, en cierto modo parecido a la zampoña escocesa”; el 'aulós' era una especie de oboe, introducido en Grecia por los auledas de Frigia desde el siglo VIII a. C. Cuando el coro era mixto de adultos y jóvenes, éstos cantaban en una octava superior. Pero los griegos -señala M. Lenchantin- "no conocieron la 
polifonía tal como es ahora para nosotros. Ellos entendían por 'polifonía’ no la multiplicidad simultánea de sonidos, sino la multiplicidad de sonidos iguales (de muchas voces) empleados en el curso de una pieza musical”.

¿Y por qué se privilegiaba al 'aulós’ como instrumento acompañante? Como expone Jean-Pierre Vernant, a la máscara y al ‘aulós’ los une una viejísima asociación. El autor acude hasta la raíz sánscrita 'garg' para explicar la relación entre la máscara y las horribles tres Gorgonas, 'hijas de la noche’, una de las cuales, Medusa, producía "un sonido aterrador, gutural, un aullido animal que salía con gran fuerza de la garganta enorme”. Y cita el verso 868 del Heracles de Eurípides:

dáion, tóde dáion mélos epauléitai

(“¡horrible, horrible es la música de ese oboe!”)

Se da, pues, un registro visual unido al registro sonoro del "grito agudo, inhumano. El mismo grito de ultratumba que sale de la boca de los muertos en el Hades”, cuya voz, como creemos (¿no apela al juicio de ellos Antígona en la tragedia homónima?), puede alguna vez interpretar el coro. Al niño interior que pervivía en los espectadores griegos lo amedrenta 'ese terror que estremece'. En ocasiones un demoníaco poder vengador ('alástor', del verbo ‘alastóo': 'no poder o no querer olvidar’) asciende desde el inframundo para reivindicar un 'míasma': una mancha criminal que pesa sobre él o sobre su raza. Algo que en el Edipo Rey, por ejemplo, sin aparecerse verdaderamente como fantasma, podríamos decir que sobrevuela simbólicamente a lo largo de la mayor parte de la obra.

Téngase en cuenta, por otra parte, que para los griegos la música, como la magia, influía poderosamente sobre la 'psyjé' (recuérdese el simbólico mito de Orfeo en los Infiernos). Platón sabía que “determinadas combinaciones de sonidos podían fortalecer el carácter humano, otras, en cambio, lo debilitaban (...)”, como señala Sachs, que añade: “toda esta concepción (mágica) de la música se sometió a fines peda- 
JOSÉ BARBA

gógicos. La idea procedía de Egipto, pero los griegos la interpretaron científicamente como 'katartiké', como enseñanza purificadora (...) La antigua magia ejercía al mismo tiempo que la música el arte curativo”. Así, pues, limpieza interior y curación van asociadas. Véanse, un poco más adelante, las implicaciones de esto con el tratamiento que Aristóteles da al concepto en su Poética.

El actor ('jipocrités') llevaba parsimoniosamente indumentaria de remoto origen oriental adecuada a su estado como personaje: túnica de pliegues ('jimátion’) para los papeles masculinos y femeninos; los 'péploi’ los usaban las mujeres; eran elegantes vestidos largos, sin mangas, atados con prendedores sobre los hombros desnudos; el 'jitón’ era una túnica recortada, para jóvenes o soldados; la ‘jláine’ era una capa larga que se recogía sobre la espalda; el ‘jlainíon’ era una capa corta. A veces usaban sombreros de diverso tipo, sobre todo cuando aparecían por la parte izquierda del escenario, para indicar que venían del campo.

Para ayudar a la visión de los espectadores de las graderías altas, los actores y los 'coreutas' llevaban grandes máscaras de expresión fija: de serenidad, de dolor, o de alegría, tal como aparecen aún, labradas en piedra o modeladas en yeso, sobre la fachada de ciertos teatros nuestros de provincia. Añadiremos, señalando, sin embargo, que hay otras interpretaciones de la palabra y que el citado J. P. Vernant prefiere, válidamente, una etimología que relaciona el término 'persona' con un origen etrusco ‘Phersu’ y a éste con el Perseus griego y con Perséfone, diosa infernal, que 'persona', el vocablo latino equivalente del 'prósopon', también para su uso en el teatro, nos recuerda otra de las funciones de este dispositivo: era una ayuda auditiva para los espectadores distantes, pues, al lanzarla el personaje, su palabra 'per-sonaba' ('per-sonare'), es decir re-sonaba fuertemente a través de la cavidad de la máscara, a modo de bocina. Basta que abombemos las dos manos en torno a la boca y pronunciemos algo a fin de darnos cuenta de lo que aquí intentamos explicar. Hemos de añadir, con todo, que los mismos griegos que con plena intención deformaron visualmente las columnas del Partenón para provocar en el visitante una percepción 
visual 'normal', fueron capaces también de lograr en sus teatros abiertos una gran técnica acústica, increíble para quienes no la hayan constatado in situ personalmente. En tales teatros, por ejemplo, -señala C. Sachs“todo el pueblo escuchaba, conteniendo la respiración, las interpretaciones de los citarodas; el silencio era tan absoluto que los más finos detalles del instrumento se hacían perceptibles en el enorme local descubierto".

Y, siendo fija la expresión de las ‘prósopa’, ¿cómo se lograba convencer al público de la verosimilitud de los sentimientos?: para la actuación era muy importante un perfecto dominio de la dicción, no sólo por los diversos papeles que un mismo actor debía representar, sino también para distinguir, en esa lengua, tan dignamente solemne y de vocales largas y breves bien diferenciadas, entre las simples palabras y el canto, y para poder transmitir claramente el grado de emoción de los personajes.

Además de la indumentaria de los actores, contaba el teatro antiguo con algunas técnicas de decoración escenográfica ('skenografía'), la cual fue mejorada por Sófocles. Se hacía uso también de la 'tramoya' y de una grúa elemental ('mejané') para levantar, según la necesidad, a algunos personajes, como hemos visto elevar por el aire a los artistas del Cirque du Soleil. Se daba la ilusión de entrar visualmente en ciertos interiores de casas o palacios al mover rápidamente una gran plataforma giratoria sobre ruedas ('enkicléme') dividida en tres o cuatro sectores circulares. Y, como en cierta ejecución de 1966, con la gran soprano sueca Bridget Nilssen, de la ‘Invocación del fuego’ de La Walkiria de Richard Wagner, para una de cuyas escenas se inventó una enorme lámina vibradora de aleación especial que semejara al trueno, poseían también los entusiastas ‘ingenieros’ escenografos griegos un 'brontéeion’ o instrumento creado específicamente para imitar la resonancia espacial de “la voz, entre las nubes, de Zeus tonante”: ('brontée’= trueno).

En la época clásica la acción era unitaria, sin distracciones secundarias y, excepto la de escenas truculentas o muy violentas, se representaba ante el público de modo continuo. El tiempo de la acción de la historia representada era 'homodiegético': el mismo de la duración de la puesta en escena; en él se unía la percepción diacrónica de los perso- 
JOSÉ BARBA

najes del drama y del público espectador. Toda complementación no actuada pero informativamente necesaria se comunicaba por medio de referencias en los parlamentos de los actores. Los personajes eran los estrictamente requeridos y se mostraba en ellos unidad de carácter de principio a fin, sin que esto indique negar la influencia que el sufrimiento, por ejemplo, podría infligir en ellos a lo largo de la 'historia' o la ‘necesidad dramática’ de la manifestación de facetas de la personalidad o de los efectos de los 'movimientos propios del alma' en determinadas circunstancias.

Notas sobre el coro: "Si logramos entender el coro, habremos entendido el núcleo y el corazón de la tragedia griega”, escribe Gilbert Murray en Eurípides y su época. Los dramaturgos griegos recurren a la danza, algo muy antiguo. Pero en la tragedia no significaba baile. Las palabras del coro, que a modernos irreflexivos podrían parecer superfluas contienen en la obra antigua una actitud reverencial, de apoyo no-intervencionista y que expresa algo de lo que "queda siempre un residuo, algo que ninguna de las figuras en acción puede haber sentido personalmente y que sólo puede traducirse en música o gestos corporales”. Sugiere a veces una danza casi estática, como de un pelotón de sombras, de emoción religiosa, como de plegaria, de rara belleza.

Como dice Arthur E. Haigh, citado por G. Murray, su función, elevada y trascendente, es 'derramar un esplendor lírico sobre el conjunto', dando al acto particular un valor universal y eterno. "El coro -añade Murray- no pertenece al plano de la experiencia cotidiana (...) sino a un mundo más encumbrado (...). No obstante lo expuesto en la sección anterior, relaciónese lo que se dice a continuación con lo escrito en la primera sección de la segunda parte de esta Introducción: “El primero y más normal elemento del coro es procurar una impresión de alivio; hacer que el mundo ideal cure las heridas del mundo real (...): una transición del horror y del dolor a la belleza o a la música (ahora) puras, casi sin cambiar nada en la situación patética. Es decir que, si el dolor os ha hecho llorar, la belleza cambiará el sabor de vuestras lágrimas, pero sin enjugarlas (...). El lamento mortal ya no proviene de la estancia cercana: es el eco de todas las criaturas que han sido desde 
los albores del mundo (...), que ya reposan en paz y cuyo lejano sufrimiento se ha convertido en misterio..."

Son, por ello, la voz del recuerdo ancestral de la raza, de la prudencia cautelosa antes del error, y de la compasión después de la dolorosa caída. Por venir resonando el contenido de su experiencia desde el origen de los tiempos humanos, el coro griego nos habla a todos con un tono igual. Como perennes guías de hombres esas voces pastorean simultáneamente el alma del poeta dramático que escribió la pieza, las de los míticos héroes cuyo quebranto se revive, las de los actores que los representaban, las del pueblo que reverencialmente contemplaba la puesta en escena, y las nuestras, sujetas también por siempre a semejantes confusión, perplejidad y angustia. Por encima de todo, "la memoria, así interpretada, posee un poder mágico”, dice Murray, y nos recuerda las palabras de uno de los ensayos de Bertrand Russell: "El pasado no admite mudanzas ni luchas (...) Cuanto había de impaciencia o codicia, cuanto era transitorio o miserable, ha desaparecido. Y sólo lo hermoso y lo eterno siguen palpitando como astros en la noche."

\section{La estructura de una obra dramática griega}

Aristóteles, en su Poética, define extensamente la tragedia como: "la representación de una acción seria, completa en sí misma y de cierta magnitud; en un lenguaje embellecido con varias clases de hermosura, cada una de las cuales tiene su lugar correspondiente en las diversas partes, en forma dramática y no narrativa y que, además, mediante una serie de hechos que suscitan piedad y terror tiene por efecto elevar y purificar el ánimo de pasiones semejantes”.

Por la fuerza de sus orígenes, la tragedia ática poseyó siempre partes cantadas y partes recitadas, pero gradualmente fue disminuyendo la importancia del canto. Al margen de lo que hoy entendemos por orquesta (orjéesra’ en griego significa “el lugar en que danza el coro”), la 
JOSÉ BARBA

música instrumental de la obra trágica se reducía al mencionado acompañamiento del aulós'.

Reteniendo en mente lo dicho en el párrafo tercero de la sección II, añadiremos que una tragedia griega se compone de: el 'prólogo', dialogado; el 'párodos' o entrada del coro, y de episodios, generalmente tres, separados por los cantos ('stásima’) del coro ('jorós’). El coro, una vez introducido, permanecía a la vista del público y en ocasiones ejecutaba una danza de movimientos mesurados. Hay un 'éxodos', desenlace o, propiamente, 'salida', porque al final de la obra el coro abandona la 'orjéesra'. En cuanto al número de los episodios hubo excepciones: por ejemplo, en Edipo Rey la obra consta de cuatro, no de tres.

\section{La ubicación y construcción de los teatros}

Como informa minuciosamente $\mathrm{D}$. Mayor, poco tiempo después de su principio los teatros estaban formados por estructuras y andamiajes de madera. Por ello, en el año 478 a.C., dado el hacinamiento multitudinario de miles de espectadores, al igual que en nuestro propio tiempo, se produjeron desgracias similares a las ocurridas en algunos malhadados estadios modernos. Al encargado de esas instalaciones de madera provisionales se le llamaba 'arjitéctoon'. Posteriormente ese mismo superintendente fue adquiriendo el significado que damos ahora al vocablo, cuando se inició la estructuración propiamente dicha de los centros fijos de representación dramática.

Aunque también se construyeron algunos pocos teatros urbanos, al aire libre, como el de Dionisos, redescubierto al pie de la Acrópolis de Atenas, en 1862, la dramaturgia hizo honor a sus orígenes agrestes con la puesta en escena de las tragedias en un medio campestre. El estar al aire libre era también otra característica común a los recintos sagrados y a los teatros. Había entre ellos una 'simpatía de afinidad', como señala J. Donald Hughes en La ecología de la civilizaciones antiguas. Todos los dramaturgos griegos -nos recuerda- usan imáge- 
nes de la naturaleza. Y pensamos nosotros en la hermosísima descripción de las proximidades de Colono (véase la sección III de la segunda parte) en cuyas alabanzas rompe a cantar el coro, a mitad de la tragedia, cerca de los bosques entre los cuales desaparecerá Edipo definitivamente al final de la obra dramática que, en su título, ha unido esos dos nombres para siempre.

¡Son tantos y tan nobles los viejos teatros griegos abiertos al purísimo cielo azul! Como el de Epidauro, aún funcional, situado cerca de la encantadora ciudad marítima de Nauplio, en el Peloponeso. Hasta la actualidad se conservan en la Grecia propiamente dicha, o con restos de nobles ruinas, el de Megalópoli en Arcadia y el de la isla de Delos, el de Side en el Asia Menor, la actual Turquía, y en los territorios de las antiguas colonias del sur de Italia, la Magna Grecia, anfiteatros semejantes, como el de Segesta o el de Siracusa, en Sicilia. La mayor parte de estos teatros conservan la forma de la acogedora cavidad de las colinas: como si la caída de una enorme y poderosa piedra frontal hubiese causado una expansión lateral excéntrica ascendente de alineadas y segmentadas graderías-asiento de mármol o cantera, en secciones con forma de cuña ('kerkides'), a partir del 'proédrio', conjunto de lugares reservados para los sacerdotes, los ministros del estado, embajadores y personajes de alto rango invitados, que abrazaba, al pie del hemiciclo del inicio de las graderías, la 'orjéesra' semicircular en sus orígenes y circular sólo más tarde. Vitruvio, arquitecto romano (88-26 a.C), observó y describió la 'platea' del teatro griego “como un círculo dentro del cual se ha diseñado un cuadrado de tal forma que las cuatro esquinas tocan la periferia”, al frente el escenario, atrás la gradería. Y, “en el centro de él está el 'timele’, el altar de Dionisos que, al mismo tiempo, forma el punto central de las danzas corágicas”.

Al fondo de la 'órjéesra' se edificó después la 'skené', una estructura como de dos pisos de alto, y, frente a ella, luego, el 'proskénion', semejante al escenario de nuestros teatros modernos. Si observamos la composición física de los teatros construidos en el abrazo natural de las colinas y pensamos filológicamente cómo en griego cavidad se dice ‘koilée’; gradería, ‘kóilon’ y que ‘koilía’ significa vientre, podría- 
JOSÉ BARBA

mos intuir, quizá algo más que poéticamente, que en aquellas grandiosas representaciones la Madre Grecia quería acoger a sus hijos en su regazo para educarlos religiosa y cívicamente, como sugerimos al final de los dos primeros párrafos de la sección III.

\section{Segunda parte}

\section{Los grandes dramaturgos clásicos}

El iniciador de la tragedia, Thespis, hacia el año 534 a.C., va de pueblo en pueblo llevando los humildes elementos de su teatro en un pequeño carromato. Después de él, Coerilos de Atenas (ca. 540-480 a.C.) parece haber sido muy fecundo como autor. De Frínico (fin del s. VI a.C.), inmediato predecesor de Esquilo, aceptado grandemente tanto por los letrados de la época como por el pueblo, cuenta Heródoto que su tragedia La toma de Mileto, representada hacia el año 492 a.C., hizo llorar a todos los asistentes. De estos primitivos autores quedan sólo escasos fragmentos.

34 En el cielo estelar de la literatura griega clásica refulge la constelación triádica de Esquilo (525-456 a.C.), Sófocles (495-405 a.C.) y Eurípides (480-406 a.C.). Como en los dos 'Siglos de Oro' que siguieron a la Reconquista española y a la Conquista de América, de igual manera, después de la victoria sobre los persas (479 a.C.), en la Atenas de 'el siglo de Pericles”, se dio el máximo esplendor, gracias a ese gran favorecedor de la formación de pléyades y fautor de todas las artes.

Las creaciones de los tres principales dramaturgos se nutren de los grandes temas heredados, ante todo, de la épica homérica: Ifigenia en Áulide (405 a.C.) de Eurípides; de la rica mitología griega: Edipo Rey; y de la historia de la Hélade, aun de hechos relativamente recientes: Los persas (472 a.C.) de Esquilo. Mas, aunque presentan personajes ricos en virtudes humanas, de pensamientos elevados y actitudes generosas, especialmente por parte de las mujeres, sobre su obra pende, como fue estudiado, con poquísimas excepciones (el tratamiento de 
D. Mayor es suficientemente cuidadoso) por los principales comentaristas clásicos, sobre todo a partir del siglo XIX, un profundo negativismo de la vida, percibida como misterio insondable, sobre todo para aquellas mentes precristianas. Las ideas de los pensadores anteriores y contemporáneos de los dramaturgos de aquella época son extremadamente relativistas. "Hasta del hedonismo se sacan deducciones negativas”, dice D. Mayor: “Si el placer constituye valor de la vida, falta en la gran masa de los hombres su fin y queda su vida sin valor.” El mismo comentarista nos recuerda al sofista Antifonte (480-411 a.C.), que escribió: "Toda la vida, hombre que te consideras feliz, ofrece un buen fundamento de acusación: no contiene nada excelso ni grande y elevado, sino que todo es pequeño, endeble, pasajero y mezclado con grandes sinsabores...” Amargura aun menor que la que Goethe, encarnando la idea de Sófocles, expresa cuando dice de las potencias celestiales: “...nos introducís en la vida, dejáis que el pobre se haga culpable, y después le abandonáis a su dolor, pues toda culpa se pena sobre la tierra”. Contrapuesta a las posteriores doctrinas éticas de Aristóteles sobre la posibilidad de construir una razonable felicidad, tal vida parece una quimera inalcanzable.

A pesar del entusiasmo nacional y la ‘reconstrucción’ que, como se dijo, siguieron al triunfo bélico sobre los persas, dado el peso permanente de las preocupaciones filosófico-religiosas de los griegos, las condiciones anímicas descritas en el párrafo anterior recuerdan la situación existencial de la Segunda posguerra mundial, cuando los dramaturgos europeos se nutrían del pensamiento de la época o eran los filósofos mismos -sobre todo Jean Paul Sartre (1905-1980), Albert Camus (1913-1960), Gabriel Marcel (1889-1973)- los que vertían sus ideas en medios literarios (el ensayo, la novela y el teatro mismo) para lograr su más amplia difusión; todos ellos precedidos, un siglo atrás, por el pesimismo de Arthur Schopenhauer (1788-1860), quien tanto se acercó al pensamiento griego del mismo Sófocles. D. Mayor cita, a tal propósito, al filósofo alemán: "El sentido de la tragedia es la profunda comprensión de que el héroe no paga pecados personales, sino el pecado de existir.” 
JOSÉ BARBA

Sobre la psique colectiva griega influían fuertemente varios siglos de la oída vivencia de la épica homérica. Los temas del ascenso y caída de los héroes helénicos y de las grandes familias nobles eran del dominio común. Trajeron profundas reflexiones a los pensadores, y podemos imaginar que provocaron muchas lágrimas en el pueblo que escuchó la declamación de los rapsodas en las plazas públicas. Por otra parte, en la efervescencia filosófica de finales del siglo VI y del siglo v a.C. se suscitaban cuestiones de revisionismo social y político, que también aprovecharían el vehículo de antiguos conflictos míticos para revestir y dar patetismo a sus ideas. No es lo mismo que varias mentes filosóficas discutan ilustradamente la contraposición entre la 'Fýsis' (Naturaleza) y la 'Nómos’ (Ley) que dar carne y sangre a estos conceptos en el drama doblemente espectacular de la precedencia de un deber moral de piedad familiar ante una obligación de estado. Por encima de lo menos esencial de las obras, son las más hondas y permanentes angustias y preocupaciones humanas las que alientan en lo más profundo de la tragedia griega: por ello éstas han pervivido y pervivirán como las pirámides de Egipto, y con mayor perennidad.

II. Sófocles, genio entre dos genios

Para completar las siguientes observaciones se podría consultar, con útil brevedad y provecho, particularmente la obra de Luis Alonso Schökel (Historia de la literatura griega y latina, 1969, Santader, Sal Terrae). Sófocles recibió con las siete obras trágicas conservadas de Esquilo (y con otras, desgraciadamente perdidas, como explicaremos al final de la segunda parte de esta introducción) un teatro poderoso, y rico en lirismo coral, personajes grandiosos, pero sobrios, de inspiración épica en los temas y en la forma narrativa; heredó la preocupación por la fuerza del hado; se potenció con la energía en la expresión, la brillantez imaginativa y la atrevida originalidad de su predecesor.

Eurípides, del cual conservamos nueve dramas, habrá de sobresalir, después de Sófocles, por la intriga variada y hábil de la acción y por la 
complejidad y el patetismo de sus escenas. Sus personajes serán reales. Se interesará, sobre todo, por la lucha de las pasiones. Su estilo será digno siempre, 'filosófico', sentencioso. Aunque Friedrich Nietzsche atacó, en El origen de la tragedia, al teatro de Eurípides por haber perdido, según él, la fuerza de Esquilo y de Sófocles y lo tildó de humanamente inauténtico por haberse sometido su autor a la doctrina moralizante de Sócrates (469-399 a.C.), algunos consideran sus obras como las segundas en calidad dentro de la dramaturgia helénica.

III. La aportación sofoclea a la literatura universal y al mundo interior del hombre

Sófocles nació en Colono, cerca de Atenas, en el año 495 a.C. A pesar de su voz escasa, participó desde jovencito en representaciones teatrales. Estudió música y lírica con los mejores maestros de la época. A los veintiocho años venció a Esquilo, veintiún años mayor que él, en un concurso de dramaturgia, cuando su predecesor era el máximo poeta trágico de Atenas.

De las ciento veintitrés tragedia reseñadas por los filólogos alejandrinos a los que nos referiremos al final de esta segunda parte, de Sófocles sólo conservamos siete, que, en orden cronológico de creación, son: Ayax (s.d), Antígona (411 a.C.), Electra (s.d.), Edipo Rey (s.d.), Las Traquinias (s.d.), Filoctetes (409 a.C.) y Edipo en Colono, representada póstumamente el año 401 a.C. De éstas la mejor, a juzgar por la elección que de ella hizo Aristóteles para su comentario en la Poética, es Edipo Rey. (E Igor Stravinsky (1882-1971) manifestó también su predilección al componer en Paris (1927) su Oedipous Rex, ópera-oratorio en dos actos siguiendo el texto de Sófocles.) De estas obras, prescindiendo de su cronología, Edipo Rey, Edipo en Colono y Antígona presentan un 'caso' secuenciado. Y aunque al final del ciclo dramático observamos la recuperación del héroe por cierta tardía clemencia divina, la historia trata fundamentalmente de su ascenso y de su caída. 
JOSÉ BARBA

Esto último es muy importante y en ello se debe observar la ejemplificación perfecta de la intención del autor: se trata de transmitir no sólo un tema teatral de origen épico (por lo demás esencialmente ya conocido por casi todos, hasta por los niños, en la Grecia de entonces, como dijimos), sino de inducir a la multitud como ciudadanía a una vivencia en común y a una sentida reflexión inmediata de las causas y de las consecuencias de la caída del héroe. Para mayor ejemplaridad, la figura del personaje principal, como Edipo, sujeto de la fatalidad ('Móira'), ha de ser muy impresionante. De modo que, ante él, los espectadores pueden ejercer como tres direcciones de mira: hacia arriba, al principio; conforme el personaje declina, horizontalmente; $\mathrm{y}$, al final, de alguna manera, hacia abajo. Es así como Sófocles nos 'hermana' con Edipo al reducir gradualmente su inicial grandeza, emparejarlo con nosotros e, incluso, ponerlo, desgraciado, a nuestros pies: para provocar en nosotros el sentido de la compasión y la meditación sobre la enorme 'Fragilidad del bien', para decirlo con un acertado título de Martha Nussbaum. Es ésta una parte del proceso de la 'kázarsis' a la que se refiere Aristóteles en su Poética. Es materia de análisis y discusión el determinar si la intención de Sófocles en su Edipo Rey fue o no atribuir la razón de la caída del héroe exclusivamente a la fatalidad ('Móira'), o si sutilmente nos invita a reflexiones ulteriores sobre la 'jamartía' (error) por deficiencia de 'aretée' (virtud), porque en esta obra-como señala Aristóteles- “queda carente de solución la antinomia entre el Destino ineludible y la culpa”.

Antígona. Por encima de los otros dramas de Sófocles, esta pieza ha fascinado siempre por su tierna, aunque firme, simpatía humana. Junto con un conflicto secundario que hoy se llamaría 'generacional', nos presenta una contraposición de índole política y moral de mucha actualidad entonces por la discusión filosófica introducida por los sofistas entre los conceptos de ‘Fýsis’ y ‘Nómos', como ya lo sugerimos más arriba.

Observar en las obras de Sófocles su gran habilidad en el desarrollo de las complejas tramas, la vivacidad de los diálogos y, en ocasiones, el sentido lirismo. Ver la ideal humanidad de los sentimientos de sus 
caracteres, su unidad y constancia. Discutir, -insistimos, pues ello es de grandísima importancia por sus implicaciones morales- si, a pesar del influjo de la 'Móira' implacable, el dramaturgo, como acabamos de sugerir, da cabida o no a una la relativa autonomía y responsabilidad de sus personajes. En la participación de sus coros gozar de la viveza de sus descripciones, de la abundancia de sus imágenes, de la naturalidad del diálogo. Y, acompañados simultáneamente por Sócrates, Sigmund Freud y el Sherlock Holmes de Arthur Conan Doyle, asistir a la aplicación insólita del asedio de una mayéutica plural en el primero y más penoso ejercicio de introspección profunda en una búsqueda, no planeada, del insospechado verdadero 'yo'. Así, sabremos cómo la 'ironía' socrática, llevadera, amistosa, instructiva, se torna en Sófocles dolorosamente ambigua y envolvente cuando un hombre, por no haber seguido a tiempo los alcances del consejo del oráculo de Delfos: 'Conócete a ti mismo', termina siendo el sabueso de su propia sombra moral, que, como sabemos, le da caza y, hasta su muerte, nunca lo abandona.

\section{IV. ¿Y cómo llegaron hasta nosotros las obras de los trágicos griegos clásicos?}

Ya sabemos que los dramas se escribían para ser representados, gozados como espectáculo por la colectividad reunida. En términos generales debemos descartar la idea de que el drama fuese para ser leído. Pero los papiros, no sólo los actores que memorizaban los papeles, tenían que transportarse, como desde hace tiempo las partituras acompañan a los intérpretes musicales. Albin Leski señala que "los siglos más peligrosos para la fidelidad al texto original fueron los dos que siguieron inmediatamente al florecimiento de la tragedia ática, o sea la época anterior a la intervención decisiva de la labor de los eruditos” (de Alejandría en Egipto). Y no menor peligro ve en la memoria falible y en las libertades que se tomaban los actores mismos con la escritura original. Eran muchas las interpolaciones, hasta que el orador y hombre de estado, también llamado Licurgo, en el último tercio del siglo II a.C., 
JOSÉ BARBA

ordenó establecer un architexto normativo y que se conservase un ejemplar 'oficial' de las obras de los tres grandes trágicos. Ése debía ser en adelante obligatorio para todas las representaciones. Filadelfo (304-247 a.C.), el segundo de los reyes Ptolomeos, con igual intención llevó a Alejandría una copia de aquel ejemplar. AAristófanes de Bizancio (257-180 a.C.), uno de los directores más dedicados de la famosa Biblioteca de Alejandría es hasta quien debe remontarse nuestra gratitud por la ‘fijación’ segura de los textos ('keiména'). Posteriormente, Dídimo de Alejandría, contemporáneo de M. T. Cicerón (106-43 a.C.), confirmó la labor de sus predecesores.

La Biblioteca de Alejandría, fue 'reinagurada' por el presidente de Egipto, Mohammed Josni Mubarak, apenas el 16 de Octubre del 2002. La primera, fundada por los dos primeros Ptolomeos, -Ptolomeo I, Soter, (360-283 a.C.) y Ptolomeo II, Filadelfo, (304-247 a.C.)- sufrió total destrucción en el año 640 d.C. A. Leski nos ofrece muy precisos detalles y explicaciones: el catálogo de la Biblioteca alejandrina llegó a contar con cien mil obras. Entre ellas llegaron a hallarse ciento veinte reconocidas como de Sófocles. De ésas sólo han llegado hasta nosotros las siete mencionadas anteriormente. Como los textos alejados del lenguaje y de las instituciones de su propia época van haciéndose cada vez menos fácilmente comprensibles, desde la antigüedad fueron preparándose 'libros' de tipo escolar; y es lo más probable que fuese así como las siete obras señaladas llegaran a constituir esa parte selecta del 'canon occidental', como lo llama Harold Bloom. Hubo errores de trasmisión, debidos también al mal entendido celo de algunos filólogos bizantinos del siglo XIII y a descuidos, incluso, de copistas posteriores cuya intervención tentaría la imaginación de Jorge Luis Borges y de Umberto Eco; pero en conjunto es a aquellos hombres amorosamente cuidadosos y a los editores renacentistas (a Aldo P. Manucio, por ejemplo, editor de Edipo Rey, Venecia, 1502) a quienes debemos nuestro agradecimiento por habernos conservado esta parte de lo que el oxoniense R. W. Livingstone llamó “El legado de Grecia”. 